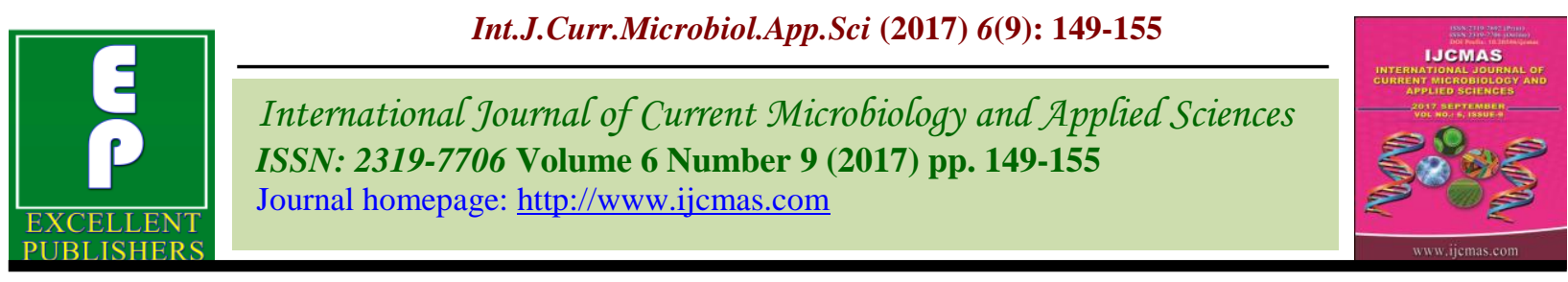

Original Research Article

https://doi.org/10.20546/ijcmas.2017.609.018

\title{
Integrated Disease Management of Turcicum Leaf Blight of Maize Caused by Exserohilum turcicum
}

\author{
T.A. Wani ${ }^{1 *}$, G.N. Bhat ${ }^{2}$, Mushtaq Ahmad ${ }^{3}$ and A. Anwar ${ }^{4}$ \\ ${ }^{1}$ Department of Plant Pathology, FOA SKUAST-K Wadura Sopore, India \\ ${ }^{2}$ Division of Plant Pathology, ${ }^{3}$ Directorate of Extension, ${ }^{4}$ Division of Plant Pathology, \\ SKUAST-K Shalimar Srinagar, India \\ *Corresponding author
}

\section{A B S T R A C T}

\begin{tabular}{|l|}
\hline Ke y w o r d s \\
Bioagents, \\
Exserohilum \\
turcicum, \\
Fungicides, Maize, \\
Plant extracts. \\
\hline Article Info \\
\hline $\begin{array}{l}\text { Accepted: } \\
\text { 04 July } 2017 \\
\text { Available Online: } \\
\text { 10 September } 2017\end{array}$ \\
\hline
\end{tabular}

The experiment on integrated management of turcicum leaf blight of maize caused by Exserohilum turcicum (Pass.) Leonard and Suggs were conducted at Sher-eKashmir University of Agricultural Sciences and Technology of Kashmir, Shalimar Campus Srinagar in a randomized block design with three replications. Excellent non-systemic and systemic fungicide, bioagent and Plant extract evaluated in vitro against Exserohilum turcicum, were integrated in field for two years during Kharif 2012 and 2013 and studies revealed that all the treatments were significantly superior over control in reducing disease intensity. Among the treatments, the disease intensity ranged from 3.57 to 17.00 per cent as against 20.45 per cent in control. Seed treatment with mancozeb 75 WP @ 0.25 per cent followed by two foliar sprays with propiconazole 25 EC @ 0.1 per cent at 40 and 50 days after sowing proved most effective treatment with minimum disease intensity of 3.57 per cent and maximum grain and stover yield of $56.95 \mathrm{q} / \mathrm{ha}$ and $15.57 \mathrm{t} / \mathrm{ha}$, respectively.

\section{Introduction}

Turcicum leaf blight of maize (Zea mays L.), popularly known as Northern Corn Leaf Bight (NCLB) in the United States of America caused by Exserohilum turcicum (Pass.) Leonard and Suggs. was first reported by Passerini in 1876 from Perma, Italy and causal organism was named as Helminthosporium turcicum. Later Leonard and Suggs in 1974 renamed the causal organism as Exserohilum turcicum as he observed that conidial hilum was protruding outwards. In India the disease was first reported by Butler et al., (1920). Later the disease was reported from Kashmir (Koul, 1957) and Himachal Pradesh (Chenula and Hora, 1962). The disease is favoured by mild temperature and high humidity (Ullstrup, 1970). Heavy dews, cool temperature and frequent rains are environmental conditions conducive for disease development (Jordan et al., 1983). The disease starts at first as small elliptical spots on the leaves, greyish green in colour and water soaked. These lesions appear first on the lower leaves and as the season progresses, the lesion number increases and all the leaves are covered. The spots turn 
greenish with age and get bigger in size, finally attaining a spindle shape. Individual spots are usually 2 to 3 inch long and 0.75 inch wide. Spores of the fungus develop abundantly on both sides of the spots. Heavily infected field present a scorched appearance (Chenula and Hora, 1962). Welz and Geiger (2000) described that symptoms of the disease can range from small cigar-shaped lesions to complete destruction of the foliage and midaltitude regions, about 900-1600 m above sea level, have particularly favourable climate for the disease as dew periods are long and temperature moderate. Ogliari et al., (2005) described that temperature between $20^{\circ} \mathrm{C}$ and $25^{\circ} \mathrm{C}$, relative humidity from 90 to 100 per cent and low luminosity favour the disease. The disease is considered to be one of the most devastating diseases as its occurrence and incidence assumes greater significance resulting in reduction of grain yield by 28 to 91 per cent (Kachapur and Hegde 1988 and Harlapur et al., 2000). Use of fungicides and tolerant genotypes has been reported to be the best tool to manage turcicum leaf blight of maize. However, none of these measures singly is effective at field level and requires integration of various management practices. Integrated approach is the novel idea to manage crop diseases as it involve minimum fungicidal load in nature. Hence an attempt was made to develop integrated disease management capsule for the disease.

\section{Materials and Methods}

The most effective non- systemic fungicide (mancozeb), systemic fungicide (propiconazole), plant extract (Nimbicidin) and bio-agent (Trichoderma harzianum) evaluated in vitro were further evaluated and integrated under field conditions against turcicum leaf blight of maize. Field trials on integrated disease management were conducted during kharif 2012 and 2013 at Sher-e-Kashmir University of Agricultural Sciences and Technology of Kashmir,
Shalimar campus, Srinagar. The experiment was laid in randomized block design with $3 \mathrm{~m}$ $\mathrm{x} 2 \mathrm{~m}$ plot size, replicated thrice using turcicum leaf blight susceptible variety of maize (C 15), recommended spacing (75 cm x $20 \mathrm{~cm}$ ), fertilizer dose (FYM @ 15 t/ha; NPK and $\mathrm{ZnSo}_{4} @ 120: 60: 30$ and 20 kg /ha), irrigation (knee high, silking and grain filling stages), insect management (carbofuran 3g @ $40 \mathrm{~kg} / \mathrm{ha}$ was used before seed sowing), weed management (atrazine 50 WP @ 2 kg/ ha in 800 liters of water was used 3 days after sowing followed by one hoeing 50 DAS) and other cultural practices (earthing up at 50 DAS, etc.). Artificial epiphytotic conditions were created twice at 5 days interval with two different methods of inoculation. Firstly, fifteen days old pure culture of E. turcicum multiplied on PDA was used for artificial inoculation at $25 \mathrm{DAS}$. The spore suspension prepared in sterilized distilled water having spore load of $5 \times 10^{4}$ spores per $\mathrm{ml}$ was sprayed with atomizer on foliage of maize. Then at 30 DAS whorl drop inoculation of plants was done with E. turcicum multiplied on sorghum grains to ensure establishment of infection. The inoculations were done in the evening time. A light water spray was given $24 \mathrm{~h}$ after both inoculations to create high relative humidity for infection.

Under various treatments mancozeb 75 WP @ 0.25 per cent, propiconazole 25 EC @ 0.1 per cent and nimbicidin @ 5 per cent were applied alone as one or two foliar sprays or in combination with the first spray of propiconazole 25 EC @ 0.1 per cent and the second spray of nimbicidin @ 5 per cent at 40 and 50 DAS. In addition mancozeb75 WP @ 0.25 per cent and T. harzianum $2 \times 10^{8} \mathrm{cfu} / \mathrm{g}$ @ 0.4 per cent were applied as seed treatment alone or in combination with the above said treatments. Twenty-four treatments including one control were imposed. Observations on disease intensity were recorded using 1-5 disease rating scale (James, 1971) at silk drying stage. The grain yield and stover yield 
data were also recorded on maturity and analyzed statistically.

\section{Results and Discussion}

It is evident from the data present in table 1, that during the year 2012, all the treatments significantly reduced the disease compared to control. However, the magnitude of reduction varied from treatment to treatment. The range of disease intensity in treatments varied from 3.02 to 16.75 per cent in comparison to 19.56 per cent recorded in control with the grain yield ranging from 57.50 to $46.70 \mathrm{q} /$ ha over $45.50 \mathrm{q} / \mathrm{ha}$ recorded in control and stover yield ranging from 15.80 to 12.10 t/ha over $11.60 \mathrm{t} / \mathrm{ha}$ recorded in control. Minimum disease intensity of 3.02 per cent was recorded in treatment $\mathrm{T}_{13}$, i.e., mancozeb 75 WP (seed treatment) + propiconazole $25 \mathrm{EC}$ (two foliar sprays at 40 and 50 DAS). This was followed by treatment $\mathrm{T}_{11}$, i.e., Mancozeb 75 WP (seed treatment and two foliar sprays at 40 and 50 DAS) with disease intensity of 3.28 per cent. These two treatments, i.e., treatment $T_{13}$ and $T_{11}$ were statistically at par with each other. However, treatments $\mathrm{T}_{3}$, i.e. mancozeb 75 WP (two foliar sprays at 40 and 50 DAS), treatment $\mathrm{T}_{5}$, i.e., propiconazole 25 EC (two foliar sprays at 40 and 50 DAS), treatment $\mathrm{T}_{19}$, i.e., $T$. harzianum (seed treatment) + mancozeb (two foliar sprays at 40 and 50 DAS) and treatment $\mathrm{T}_{21}$, i.e., T. harzianum (seed treatment) + propiconazole (two foliar sprays at 40 and 50 DAS) were statistically at par showing disease intensity of $5.25,5.78,5.19$ and 5.47 per cent, respectively. Treatment $\mathrm{T}_{10}$, i.e., mancozeb 75 WP (seed treatment and one foliar spray at 40 DAS) and $\mathrm{T}_{16}$, i.e., mancozeb $75 \mathrm{WP}$ (seed treatment) + propiconazole $25 \mathrm{EC}$ (foliar spray at 40 DAS) + Nimbicidin (foliar spray at 50 DAS) with disease intensity of 6.78 and 6.23 per cent, respectively, were statistically at par with each other. Treatment $\mathrm{T}_{7}$, i.e., Nimbicidin (two foliar sprays at 40 and 50 DAS) and treatment $\mathrm{T}_{8}$, i.e., propiconazole 25
EC (one foliar spray at 40 DAS) + Nimbicidin (one foliar spray at 50 DAS) with disease intensity of 10.78 and 10.23 per cent, respectively, were statistically at par. Treatment $\mathrm{T}_{18}$, i.e., $T$. harzianum (seed treatment) + mancozeb $75 \mathrm{WP}$ (one foliar spray 40 DAS), treatment $\mathrm{T}_{20}$, i.e., $T$. harzianum (seed treatment) + propiconazole 25 EC (one foliar spray 40 DAS) and treatment $\mathrm{T}_{23}$, i.e., $T$. harzianum (seed treatment) + Nimbicidin (two foliar sprays at 40 and 50 DAS) with disease intensity of $11.42,11.72$ and 11.68, respectively, were statistically at par with each other. Treatment $\mathrm{T}_{6}$, i.e., Nimbicidin (one foliar spray $40 \mathrm{DAS}$ ) and $\mathrm{T}_{22}$, i.e., T. harzianum (seed treatment) + Nimbicidin (one foliar spray at 40 DAS) with disease intensity of 14.78 and 14.72 per cent, respectively, were statistically at par with each other. Treatment $\mathrm{T}_{15}$, i.e., mancozeb 75 WP (seed treatment) + Nimbicidin (two foliar sprays at 40 and $50 \mathrm{DAS}$ ) and treatment $\mathrm{T}_{24}$, i.e., T. harzianum (seed treatment) + propiconazole $25 \mathrm{EC}$ (foliar spray at $40 \mathrm{DAS}$ ) + Nimbicidin (foliar spray 50 DAS) with disease intensity of 8.04 and 8.98 per cent, respectively, were statistically at par with each other. Treatment $\mathrm{T}_{17}$, i.e., T. harzianum (seed treatment only) was least effective in comparison to all other treatments with disease intensity of 16.75 per cent over control $(19.56 \%)$.

During the year 2013 the experiment was repeated and results (Table 1), revealed that the treatments again proved effective in reducing the disease intensity and were significantly superior over control. The range of disease intensity in treatments varied from 4.12 to 17.25 per cent in comparison to 21.35 per cent recorded in control with the grain yield ranging from 56.40 to $45.85 \mathrm{q} /$ ha over $44.90 \mathrm{q} / \mathrm{ha}$ recorded in control and stover yield ranging from 15.35 to $11.90 \mathrm{t} / \mathrm{ha}$ over $11.30 \mathrm{t} / \mathrm{ha}$ recorded in control. 
Table.1 Integrated disease management of turcicum leaf blight of maize in cv. C 15 during 2012 and 2013

\begin{tabular}{|c|c|c|c|c|c|c|c|c|c|c|}
\hline \multirow{2}{*}{\multicolumn{2}{|c|}{ Treatment }} & \multicolumn{3}{|c|}{ Disease intensity (\%) } & \multicolumn{3}{|c|}{ Grain yield (q/ha) } & \multicolumn{3}{|c|}{ Stover yield (t/ha) } \\
\hline & & \multirow{2}{*}{$\begin{array}{c}\mathbf{2 0 1 2} \\
19.56^{*} \\
(26.24) \\
\end{array}$} & \multirow{2}{*}{$\begin{array}{c}\mathbf{2 0 1 3} \\
21.35 \\
(27.52)\end{array}$} & \multirow{2}{*}{$\begin{array}{c}\text { Pooled } \\
20.45 \\
(26.88) \\
\end{array}$} & \multirow{2}{*}{$\begin{array}{l}\mathbf{2 0 1 2} \\
45.50 \\
\end{array}$} & \multirow{2}{*}{$\frac{\mathbf{2 0 1 3}}{44.90}$} & \multirow{2}{*}{\begin{tabular}{|c|} 
Pooled \\
45.20
\end{tabular}} & \multirow{2}{*}{$\begin{array}{l}\mathbf{2 0 1 2} \\
11.60\end{array}$} & \multirow{2}{*}{$\begin{array}{l}\mathbf{2 0 1 3} \\
11.30\end{array}$} & \multirow{2}{*}{$\begin{array}{l}\text { Pooled } \\
11.45\end{array}$} \\
\hline $\mathrm{T}_{1}$ & Control & & & & & & & & & \\
\hline $\mathrm{T}_{2}$ & Mancozeb (FS) & $\begin{array}{c}13.28 \\
(21.37 \\
\end{array}$ & $\begin{array}{c}14.73 \\
(22.56) \\
\end{array}$ & $\begin{array}{c}14.00 \\
(21.97) \\
\end{array}$ & 49.60 & 49.20 & 49.40 & 13.00 & 12.80 & 12.90 \\
\hline $\mathrm{T}_{3}$ & Mancozeb (FS-FS) & $\begin{array}{c}05.25 \\
(13.24) \\
\end{array}$ & $\begin{array}{c}06.13 \\
(14.33) \\
\end{array}$ & $\begin{array}{c}05.69 \\
13.80 \text { ) }\end{array}$ & 52.70 & 52.30 & 52.50 & 14.40 & 14.10 & 14.25 \\
\hline $\mathrm{T}_{4}$ & Propiconazole (FS) & $\begin{array}{c}13.08 \\
(21.20) \\
\end{array}$ & $\begin{array}{c}14.25 \\
(22.17) \\
\end{array}$ & $\begin{array}{c}13.66 \\
(21.69) \\
\end{array}$ & 49.40 & 49.00 & 49.20 & 12.80 & 12.70 & 12.75 \\
\hline $\mathrm{T}_{5}$ & Propiconazole (FS-FS) & $\begin{array}{c}05.78 \\
(13.91) \\
\end{array}$ & $\begin{array}{c}06.45 \\
(14.71) \\
\end{array}$ & $\begin{array}{c}06.11 \\
(14.31) \\
\end{array}$ & 52.40 & 52.10 & 52.25 & 14.30 & 14.00 & 14.15 \\
\hline $\mathrm{T}_{6}$ & Nimbicidin (FS) & $\begin{array}{c}14.78 \\
(22.60) \\
\end{array}$ & $\begin{array}{c}15.52 \\
(23.20) \\
\end{array}$ & $\begin{array}{c}15.15 \\
(22.90) \\
\end{array}$ & 48.85 & 48.35 & 48.60 & 12.60 & 12.50 & 12.55 \\
\hline $\mathrm{T}_{7}$ & Nimbicidin (FS—FS) & $\begin{array}{c}10.78 \\
(19.16) \\
\end{array}$ & $\begin{array}{c}11.02 \\
(19.38) \\
\end{array}$ & $\begin{array}{c}10.90 \\
(19.27) \\
\end{array}$ & 49.95 & 49.85 & 49.90 & 13.00 & 12.90 & 12.95 \\
\hline $\mathrm{T}_{8}$ & Propiconazole (FS) —Nimbicidin(FS) & $\begin{array}{c}10.23 \\
(15.59) \\
\end{array}$ & $\begin{array}{c}10.87 \\
(16.29) \\
\end{array}$ & $\begin{array}{r}10.55 \\
(18.95 \\
\end{array}$ & 50.25 & 50.10 & 50.17 & 13.30 & 13.30 & 13.30 \\
\hline $\mathrm{T}_{9}$ & Mancozeb (ST) & $\begin{array}{c}15.28 \\
(23.01) \\
\end{array}$ & $\begin{array}{c}16.07 \\
(23.63) \\
\end{array}$ & $\begin{array}{c}15.67 \\
(23.31) \\
\end{array}$ & 48.75 & 48.30 & 48.52 & 12.50 & 12.40 & 12.45 \\
\hline $\mathrm{T}_{10}$ & Mancozeb $(\mathrm{ST}-\mathrm{FS})$ & $\begin{array}{c}06.78 \\
(15.09) \\
\end{array}$ & $\begin{array}{c}07.18 \\
(15.54) \\
\end{array}$ & $\begin{array}{c}06.98 \\
(15.31) \\
\end{array}$ & 52.20 & 51.90 & 52.05 & 14.10 & 13.80 & 13.95 \\
\hline $\mathrm{T}_{11}$ & Mancozeb (ST_FS—FS) & $\begin{array}{c}03.28 \\
(10.43) \\
\end{array}$ & $\begin{array}{c}04.76 \\
(12.60) \\
\end{array}$ & $\begin{array}{c}04.02 \\
(11.56) \\
\end{array}$ & $\mathbf{5 7 . 2 0}$ & 56.10 & 56.65 & 15.50 & 15.10 & 15.30 \\
\hline $\mathrm{T}_{12}$ & Mancozeb (ST) —Propiconazole (FS) & $\begin{array}{c}07.02 \\
(15.36)\end{array}$ & $\begin{array}{c}07.42 \\
(15.80)\end{array}$ & $\begin{array}{c}07.22 \\
(15.58)\end{array}$ & 51.40 & 51.10 & 51.25 & 13.60 & 13.40 & 13.50 \\
\hline $\mathrm{T}_{13}$ & Mancozeb (ST) —Propiconazole (FS—FS) & $\begin{array}{c}03.02 \\
(10.00)\end{array}$ & $\begin{array}{c}04.12 \\
(11.71) \\
\end{array}$ & $\begin{array}{c}03.57 \\
(10.89)\end{array}$ & $\mathbf{5 7 . 5 0}$ & 56.40 & 56.95 & 15.80 & 15.35 & 15.57 \\
\hline $\mathrm{T}_{14}$ & Mancozeb (ST) —Nimbicidin (FS) & $\begin{array}{c}9.25 \\
(17.70) \\
\end{array}$ & $\begin{array}{c}10.54 \\
(18.94) \\
\end{array}$ & $\begin{array}{c}9.89 \\
(18.32) \\
\end{array}$ & 50.35 & 50.20 & $\mathbf{5 0 . 2 7}$ & 13.30 & 13.00 & 13.15 \\
\hline $\mathrm{T}_{15}$ & Mancozeb (ST) —Nimbicidin(FS—FS) & $\begin{array}{c}08.04 \\
(16.47) \\
\end{array}$ & $\begin{array}{c}09.42 \\
(17.87)\end{array}$ & $\begin{array}{c}\mathbf{0 8 . 7 3} \\
(\mathbf{1 7 . 1 8}) \\
\end{array}$ & 50.50 & 50.45 & 50.47 & 13.40 & 13.30 & 13.35 \\
\hline $\mathrm{T}_{16}$ & $\begin{array}{l}\text { Mancozeb(ST) —Propiconazole(FS) - } \\
\text { Nimbicidin(FS) }\end{array}$ & $\begin{array}{c}06.23 \\
(14.45) \\
\end{array}$ & $\begin{array}{c}06.48 \\
(14.74) \\
\end{array}$ & $\begin{array}{c}06.35 \\
(14.59) \\
\end{array}$ & 51.80 & 51.30 & 51.55 & 13.90 & 13.50 & 13.70 \\
\hline $\mathrm{T}_{17}$ & T. harzianum (ST) & $\begin{array}{c}16.75 \\
(24.15) \\
\end{array}$ & $\begin{array}{l}17.25 \\
(24.54) \\
\end{array}$ & $\begin{array}{l}17.00 \\
(24.35) \\
\end{array}$ & 46.70 & 45.85 & 46.27 & 12.10 & 11.90 & 12.00 \\
\hline $\mathrm{T}_{18}$ & T. harzianum (ST) —Mancozeb (FS) & $\begin{array}{c}11.42 \\
(19.75) \\
\end{array}$ & $\begin{array}{c}12.62 \\
(20.80)\end{array}$ & $\begin{array}{c}12.02 \\
(20.28)\end{array}$ & 50.00 & 49.80 & 49.90 & 13.10 & 12.90 & 13.00 \\
\hline $\mathrm{T}_{19}$ & T. harzianum (ST) - Mancozeb (FS-FS) & $\begin{array}{c}05.19 \\
(13.17) \\
\end{array}$ & $\begin{array}{c}05.61 \\
(13.71) \\
\end{array}$ & $\begin{array}{c}05.40 \\
(13.44) \\
\end{array}$ & 53.80 & 53.40 & 53.60 & 14.60 & 14.30 & 14.45 \\
\hline $\mathrm{T}_{20}$ & T. harzianum (ST) -Propiconazole(FS) & 11.72 & 12.84 & 12.28 & 50.15 & 50.00 & $\mathbf{5 0 . 0 7}$ & 13.30 & 13.20 & $\mathbf{1 3 . 2 5}$ \\
\hline
\end{tabular}


Int.J.Curr.Microbiol.App.Sci (2017) 6(9): 149-155

\begin{tabular}{|c|c|c|c|c|c|c|c|c|c|c|}
\hline & & $(20.01)$ & $(20.99)$ & $(20.51)$ & & & & & & \\
\hline $\mathrm{T}_{21}$ & $\begin{array}{l}\text { T. harzianum (ST) - Propiconazole (FS- } \\
\text { FS) }\end{array}$ & $\begin{array}{c}05.47 \\
(13.52) \\
\end{array}$ & $\begin{array}{c}06.19 \\
(14.41) \\
\end{array}$ & $\begin{array}{c}\mathbf{0 5 . 8 3} \\
(\mathbf{1 3 . 9 7 )} \\
\end{array}$ & 52.75 & 52.35 & 52.55 & 14.50 & 14.20 & 14.35 \\
\hline $\mathrm{T}_{22}$ & T. harzianum $(\mathrm{ST})-\mathrm{Nimbicidin}(\mathrm{FS})$ & $\begin{array}{c}14.72 \\
(22.56) \\
\end{array}$ & $\begin{array}{c}15.18 \\
(22.93) \\
\end{array}$ & $\begin{aligned} 14.95 \\
(22.74) \\
\end{aligned}$ & 49.35 & 49.10 & 49.22 & 12.90 & 12.70 & 12.80 \\
\hline $\mathrm{T}_{23}$ & T. harzianum (ST) -Nimbicidin (FS-FS) & $\begin{array}{c}11.68 \\
(19.98) \\
\end{array}$ & $\begin{array}{c}12.92 \\
(21.06) \\
\end{array}$ & $\begin{array}{c}12.30 \\
(20.53) \\
\end{array}$ & 50.10 & 49.90 & $\mathbf{5 0 . 0 0}$ & 13.10 & 13.00 & $\mathbf{1 3 . 0 5}$ \\
\hline $\mathrm{T}_{24}$ & $\begin{array}{l}\text { T. harzianum (ST) —Propiconazole (FS) - } \\
\text { Nimbicidin(FS) }\end{array}$ & $\begin{array}{c}08.98 \\
(17.43)\end{array}$ & $\begin{array}{c}09.42 \\
(17.87)\end{array}$ & $\begin{array}{c}09.20 \\
(17.65)\end{array}$ & 50.50 & 50.15 & $\mathbf{5 0 . 3 2}$ & 13.40 & 13.20 & 13.30 \\
\hline & Overall mean & $\begin{array}{c}09.90 \\
(18.34)\end{array}$ & $\begin{array}{c}10.77 \\
(19.16)\end{array}$ & $\begin{array}{c}10.33 \\
(18.75)\end{array}$ & 50.90 & $\mathbf{5 0 . 5 0}$ & $\mathbf{5 0 . 7 0}$ & 13.50 & 13.28 & 13.39 \\
\hline
\end{tabular}

*Mean of three replications; Figures in parenthesis indicate arcsine values; ST $=$ Seed treatment; FS $=$ Foliar spray $1^{\text {st }}$ at 40 DAS and $2^{\text {nd }}$ at 50 DAS

Fig.1 Integrated disease management of turcicum leaf blight of maize in cv. C 15 at SKUAST-K, Shalimar during 2012 and 2013

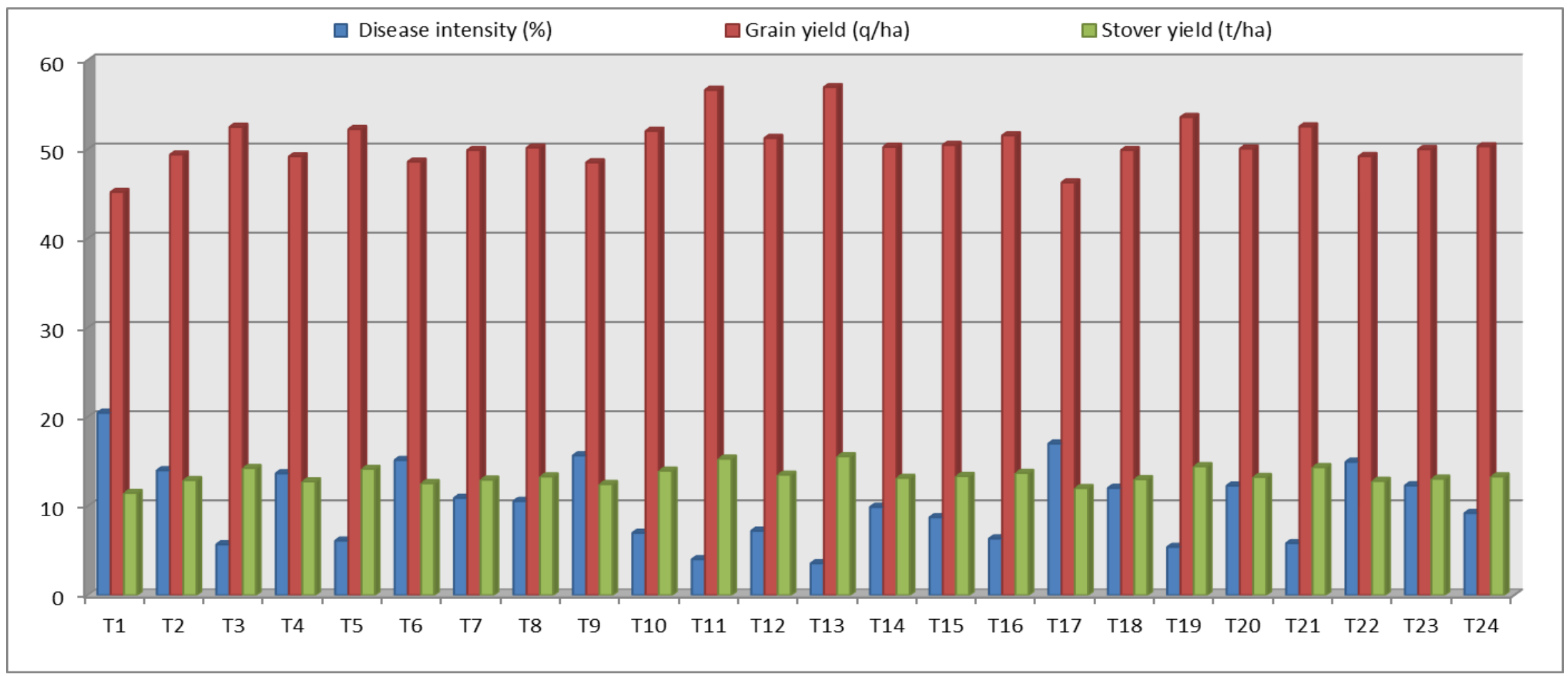


Least disease intensity of 4.12 per cent was observed in treatment $\mathrm{T}_{13}$, i.e., mancozeb $75 \mathrm{WP}$ (seed treatment) + propiconazole $25 \mathrm{EC}$ (two foliar sprays at 40 and 50 DAS) followed by treatment $\mathrm{T}_{11}$, i.e., mancozeb $75 \mathrm{WP}$ (seed treatment and two foliar sprays at 40 and 50 DAS) with disease intensity of 4.76 per cent and were statistically at par with each other. Among other treatments treatment $\mathrm{T}_{3}$, i.e., mancozeb $75 \mathrm{WP}$ (two foliar sprays at 40 and 50 DAS), treatment $\mathrm{T}_{5}$, i.e., propiconazole 25 EC (two foliar sprays at 40 and 50 DAS), treatment $\mathrm{T}_{16}$, i.e., mancozeb $75 \mathrm{WP}$ (seed treatment) + propiconazole $25 \mathrm{EC}$ (one foliar spray at 40 DAS) + Nimbicidin (foliar spray 50 DAS) and treatment $\mathrm{T}_{21}$, i.e., T. harzianum (seed treatment) + propiconazole 25 EC (two foliar sprays at 40 and 50 DAS) with disease intensity of $6.13,6.45,6.48$ and 6.19 per cent, respectively, were statistically at par. Treatment $\mathrm{T}_{2}$, i.e., mancozeb $75 \mathrm{WP}$ (one foliar spray at 40 DAS) and treatment $\mathrm{T}_{4}$, i.e., propiconazole (one foliar spray at $40 \mathrm{DAS}$ ) with disease intensity of 14.73 and 14.25 per cent were statistically at par. Treatment $\mathrm{T}_{6}$, i.e., Nimbicidin (one foliar spray at $40 \mathrm{DAS}$ ) and treatment $\mathrm{T}_{22}$, i.e., $T$. harzianum (seed treatment) + Nimbicidin (one foliar spray at $40 \mathrm{DAS}$ ) with disease intensity of 15.52 and 15.18 per cent, respectively, were statistically at par. Treatment $\mathrm{T}_{8}$, i.e., propiconazole $25 \mathrm{EC}$ (one foliar spray at 40 DAS) + Nimbicidin (one foliar spray 50 DAS) and treatment $\mathrm{T}_{14}$, i.e., mancozeb $75 \mathrm{WP}$ (seed treatment) + Nimbicidin (one foliar spray 40 DAS) with disease intensity of 10.87 and 10.54 per cent, respectively, were statistically at par. Treatment $\mathrm{T}_{10}$, i.e., mancozeb $75 \mathrm{WP}$ (seed treatment and one foliar spray at $40 \mathrm{DAS}$ ) and treatment $\mathrm{T}_{12}$, i.e., mancozeb $75 \mathrm{WP}$ (seed treatment) + propiconazole $25 \mathrm{EC}$ (one foliar spray at 40 DAS) with disease intensity of 7.18 and 7.42 per cent, respectively, were statistically at par with each other. Treatment $\mathrm{T}_{15}$, i.e., mancozeb 75 WP (seed treatment) + Nimbicidin (two foliar sprays at 40 and 50 DAS) and treatment $\mathrm{T}_{24}$, i.e., $T$. harzianum (seed treatment) + propiconazole (foliar spray at 40 DAS) + Nimbicidin (foliar spray at 50 DAS) with disease intensity of 9.42 per cent in both the treatments. Treatment $\mathrm{T}_{16}$, i.e., mancozeb 75 WP (seed treatment) + propiconazole 25 EC (foliar spray $40 \mathrm{DAS}$ ) and treatment $\mathrm{T}_{12}$, i.e., mancozeb 75 WP (seed treatment) + propiconazole $25 \mathrm{EC}$ (foliar spray at $40 \mathrm{DAS}$ ) with disease intensity of 7.18 and 7.42 per cent, respectively, were statistically at par with each other. Treatment $\mathrm{T}_{15}$, i.e., mancozeb $75 \mathrm{WP}$ (seed treatment) + Nimbicidin (foliar sprays at 40 and $50 \mathrm{DAS}$ ) and treatment $\mathrm{T}_{24}$, i.e., $T$. harzianum (seed treatment) + propiconazole (foliar spray at 40 DAS) + Nimbicidin (foliar spray at 50 DAS) with disease intensity of 9.42 per cent in both the treatments. Treatment $\mathrm{T}_{16}$, i.e., mancozeb $75 \mathrm{WP}$ (seed treatment) + propiconazole $25 \mathrm{EC}$ (foliar spray at $40 \mathrm{DAS}$ ) + Nimbicidin (foilar spray at 50 DAS) and treatment $\mathrm{T}_{21}$, i.e., T. harzianum (seed treatment) + propiconazole (two foliar sprays at 40 and 50 DAS) with disease intensity of 6.48 and 6.19 per cent, respectively, were statistically at par with each other. Treatment $\mathrm{T}_{18}$, i.e., T. harzianum (seed treatment) + mancozeb $75 \mathrm{WP}$ (foliar spray at $40 \mathrm{DAS}$ ), treatment $\mathrm{T}_{20}$, i.e., $T$. harzianum (seed treatment) + propiconazole 25 EC (foliar spray at $40 \mathrm{DAS}$ ) and treatment $\mathrm{T}_{23}$, i.e., T. harzianum (seed treatment) + propiconazole (foliar spray at 40 DAS) + Nimbicidin (foliar spray at 50 DAS) with disease intensity of $12.62,12.84$ and 12.92 per cent, respectively, were statistically at par with each other. Treatment $\mathrm{T}_{17}$, i.e., T. harzianum (seed treatment) proved least effective in comparison to all other treatments with disease intensity of 17.25 per cent, but was significantly superior over control (21.35\%).

Two years (2012 and 2013) pooled data presented in table 1 and depicted in figure 1 , revealed higher disease intensity of 17.25 per cent during the year 2013, in comparison to 16.75 per cent during the year 2012 with treatment $\mathrm{T}_{17}$, i.e., $T$. harzianum (seed treatment only) in both the years. All the treatments were significantly superior over control in reducing the disease intensity. Among the treatments, the disease intensity ranged from 3.57 to 17.00 per cent as against 20.45 per cent in control with the grain yield of 56.95 to $46.27 \mathrm{q} /$ ha over 45.20 
$\mathrm{q} / \mathrm{ha}$ recorded in control and stover yield of 15.57 to $12.00 \mathrm{t} /$ ha over $11.45 \mathrm{t} / \mathrm{ha}$ recorded in control.

The combined treatments, viz., Chemical + Biological + Plant extract were significantly superior over individual treatments. The results thus explain the viability of a package for the management of turcicum leaf blight of maize. Khedekar et al., (2010) conducted integrated disease management of turcicum leaf blight of maize caused by E. turcicum and found the lowest PDI $(25.66 \%)$ and the maximum grain yield $(65.48 \mathrm{q} / \mathrm{ha})$ was recorded in treatment $\mathrm{T}_{1}$, i.e., seed treatment with carboxin $(2 \mathrm{ml} / \mathrm{kg})$ followed by two sprays of mancozeb $(0.25 \%)$ at 40 and 50 DAS which was statistically at par with treatment $\mathrm{T}_{4}$, i.e., seed treatment with Trichoderma harzianum $(6 \mathrm{~g} / \mathrm{kg})$ followed by two sprays of mancozeb $(0.25 \%)$ as compared to control, wherein it recorded the highest PDI $(61.88 \%)$ and the lowest grain yield (54.88 q/ha).

\section{References}

Butler, E.J., Shaw J. F. and Mitra, A. K. 1920. Reports of imperial mycologist. Reports of Agricultural Research Institute and Collage, Pusa, New Delhi (cf: Indian Journal of Plant Genetic Resource 24(2): 343-345).

Chenula, V.V., and Hora, T.S. 1962. Studies on losses due to Helminthosporium blight of maize. Indian Phytopathology 15: 235-237.

Harlapur, S.I., Wali, M.C., Anahosur, K.H. and Muralikrishna, S. 2000. A report on survey and surveillance of maize diseases in northern Karnataka. Karnataka Journal of Agricultural Sciences 13: 750-751

James, W.C., 1971. An illustrated series of assessment keys for plant diseases, their preparation and usage. Canadian Plant Disease Survey 51: 39-65

Jordan, E.G., Perkins, J.M., Schall, R.A. and Pederson, W.L. 1983. Occurrence of race 2 of Exserohilum turcicum on corn in central United States. Plant Disease 67: 1163-1165.

Kachapur, M.R., and Hegde, R.K. 1988. Studies on Turcicum leaf blight caused by Exserohilum turcicum with special reference to crop loss assessment. Plant Pathology Newsletter 6: 33-35 (cf: Karnataka Journal of Agricultural Sciences 20(3): 665-666).

Khedekar, S.A., Harlapur, S.A., Kulkarni S., Bengani, V.I. and Deshpande, V.K. 2010. Integrated management of Turcicum leaf blight of maize caused by Exserohilum turcicum (Pass.) Leonard and Suggs. Karnataka Journal of Agricultural Sciences 23(2): 372-373.

Koul, T.N., 1957. Out breaks and new records. Food and Agriculture Organization. Plant Protection Bulletin 5(6): 93-96.

Leonard, K.J., and Suggs, E.G. 1974. Setosphaeria prolata is the ascigenous state of Exserohilum prolata. Mycologia 66: 181297.

Ogliari, J.B., Guimaraes, M.A., Geraldi, I.O. and Camargo, L.E.A. 2005. New resistance genes in the Zea mays-Exserohilum turcicum pathosystem. Genetics and Molecular Biology 28(3): 435-439.

Passerini, 1876. Lanebbia Delgranotur Co. Bol. Comiz, Agriculture. Parmense 10: 3. (cf: Karnataka Journal of Agricultural Sciences 20 (3): 655-666).

Ullstrup, A.J., 1970. A comparison of monogenic and polygenic resistance to $H$. turcicum in corn. Phytopathology 60: 1597-1599.

Welz, H.G., and Geiger, H.H. 2000. Genes for resistance to northern corn leaf blight in diverse maize populations. Plant Breeding 119: $1-14$

\section{How to cite this article:}

Wani, T.A., G.N. Bhat, Mushtaq Ahmad and Anwar, A. 2017. Integrated Disease Management of Turcicum Leaf Blight of Maize Caused by Exserohilum turcicum. Int.J.Curr.Microbiol.App.Sci. 6(9): 149-155. doi: https://doi.org/10.20546/ijcmas.2017.609.018 